\title{
Growth of Microorganisms in Propofol and Mixture of Propofol, Lidocaine and Fentanyl
}

\author{
Hatice Aysel Altan1, Esat Bonabi2, Sevgi Kesici33, Hafize Sezer4 and Veli Bulent Ucar ${ }^{5}$ \\ ${ }^{1}$ Department of Anesthesiology, Istanbul Aydin University, Vocational School of Health Services, Istanbul, Turkey \\ ${ }^{2}$ Faculty of Medicine, Department of Medical Microbiology, Istanbul Aydin University, Istanbul, Turkey \\ 3Department of Anesthesiology, Hamidiye Etfal Training and Research Hospital, Istanbul, Turkey \\ ${ }^{4}$ Faculty of Medicine, Department of Biostatistics, Istanbul Aydin University, Istanbul, Turkey \\ ${ }^{5}$ Department of Medical Laboratory Techniques, Istanbul Aydin University, Vocational School of Health Services, Istanbul, Turkey
}

\begin{abstract}
Objective: To determine the growth of microorganisms in propofol when combined with fentanyl and lidocaine in different temperatures and times in order to find out whether there is any improvement in antimicrobial effect to lengthen the safe duration of time for application of propofol.

Study Design: Cross-sectional study.

Place and Duration of Study: Istanbul Aydin University Laboratory, Istanbul, Turkey, from June to September 2018.

Methodology: The studied drugs and thier combination was used to determine their effect on bacterial growth of Staphylococcus aureus, Pseudomonas aeruginosa, Candida albicans and Acinetobacter baumanni. Bacterial solutions were prepared at 0.5 MacFarland in sterile $0.9 \%$ physiological saline and diluted at $1: 100$ concentration. Colony numbers were measured as colony forming units $\mathrm{mL}^{-1}$ at 0,8 , and 24 hours and ${ }^{\circ}{ }^{\circ} \mathrm{C}, 22^{\circ} \mathrm{C}$ and $37^{\circ} \mathrm{C}$.

Results: In general, propofol supported the growth of microorganisms. Fentanyl with propofol also promoted the growth, especially in room and body temperature at 8th and 24th hours but when combined with lidocaine, the number of CFUs was reduced significantly compared with propofol + fentanyl group. Lidocaine inhibited the growth of microorganisms in all the solutions except for candida albicans.

Conclusion: Lidocaine was shown to have antibacterial effect which carries advantage for inhibiting infections due to propofol; but aseptic technique is essential during preparation of propofol infusions. Fentanyl like propofol also promoted the growth at room and body temperatures.
\end{abstract}

Key Words: Microorganisms, Propofol, Lidocaine, Fentanyl, Anesthetic drugs.

How to cite this article: Altan HA, Bonabi E, Kesici S, Sezer H, Ucar VB. Growth of microorganisms in propofol and mixture of propofol, lidocaine and fentanyl. J Coll Physicians Surg Pak 2019; 29(9):828-32.

\section{INTRODUCTION}

Propofol (2,6-diisopropylphenol) is a popular drug for the induction and maintenance of anesthesia.1,2 This is primarily because of its rapid onset, short duration of action and minimal side effects. Its use has expanded from solely an anesthetic agent to a sedative-hypnotic agent used in the intensive care unit and in outpatient procedures; but due to its lipid formulation, it supports the growth of microorganisms. Extrinsically contaminated propofol during its application, causes wound infection and sepsis postoperatively.3-5 Therefore, syringe containing propofol is thrown away when not used for 6 hours. In order to improve the antimicrobial effect and thus lengthen the shelf life of this anesthetic agent. It is combined with some other drugs and microbial growth

Correspondence to: Dr. Sevgi Kesici, Department of Anesthesiology,

Hamidiye Etfal Training and Research Hospital, Istanbul,

Turkey

E-mail:md.kesici@mynet.com

Received: January 04, 2019; Revised: April 29, 2019;

Accepted: June 14, 2019 was investigated. 5-7 Thiopental, methohexital, lidocaine and fentanyl were shown to inhibit some microorganisms; but the antimicrobial effect of the combination of propofol with lidocaine and fentanyl, which are used in anesthesia induction, was not investigated in order to find out if there is an additive antimicrobial effect, thus causing a longer shelf life for propofol.5,8-11

Propofol is a popular drug but its injection causes pain which is relieved by the injection of lidocaine. Fentanyl, after induction with propofol is used for analgesia; and suppressing the effect of tachycardia and hypertension due to stress response to intubation.4,12,13 Although, these agents are frequently applied in induction of anesthesia, there is no data about their effect on microbial growth when combined.

The aim of this study was to determine the growth of microorganisms in propofol when combined with fentanyl and lidocaine in different temperatures $\left(4^{\circ} \mathrm{C}, 22^{\circ} \mathrm{C}, 37^{\circ} \mathrm{C}\right)$ and times $(0 \mathrm{hr}, 8 \mathrm{hr}, 24 \mathrm{hr})$ in order to find out whether there is any improvement in antimicrobial effect to lengthen the safe duration of time for application of propofol. 


\section{METHODOLOGY}

This study was conducted at Istanbul Aydin University Laboratory between June and September 2018. The antimicrobial effect of three different anesthetic drugs and saline were evaluated; propofol \%1 (Fresenius Kabi Ilaç San), lidocaine (Jetokain $20 \mathrm{mg} / \mathrm{ml}$; ADEKA IlaC San), fentanyl sitrat (Fentanyl $0.05 \mathrm{mg} / \mathrm{mL}$; Johnson \& Jonhson Sihhi Malzeme San. ve Tic. Ltd. Sti.), steril saline (Pf\% 0.9 izotonik, Polifarma).

The organisms were Staphylococus aureus (American type of Culture Collection ATCC 25923), Pseudomonas aeruginosa (ATCC 27853), Candida albicans (ATCC 10231 ve Acinetobacter baumanni (clinical isolate), several colonies of each isolate were cultured in triptic soy agar (PH Eur,USP, JP) for 24 hours. Overnight cultures were diluted to a density of $0.5 \mathrm{McF}$ arland units with $0.9 \%$ sterile saline. Each organism solution was further diluted 1:50 with 0.9 steril saline. ${ }^{11}$

For every bacteria, 3 vials for incubation at $4^{\circ} \mathrm{C}, 22^{\circ} \mathrm{C}$ and $37^{\circ} \mathrm{C}$ were prepared. Three vials for propofol $(10$ $\mathrm{ml}), 3$ vials for propofol $(8.5 \mathrm{ml})+$ lidocaine $(1.5 \mathrm{ml}), 3$ vials for propofol $(7.5 \mathrm{ml})+$ lidocaine $(1.5 \mathrm{ml})+$ fentanyl $(1 \mathrm{ml}) ; 3$ vials steril saline. $100 \mu \mathrm{l}$ of each diluted organism were added to the culture vials. Each organism solution was vortexed for 2 minutes before addition to vials. After the organisms were added, each vial was vortexed and from every vial, $1 \mu \mathrm{l}$ aliquot of each mixture was inoculated onto triptic soy agar at 0,8 , 24 hours. These plates were incubated at $4^{\circ} \mathrm{C}, 22^{\circ} \mathrm{C}, 37^{\circ} \mathrm{C}$ for 24 hours. Colony forming units (CFU mL-1) grown on the plates are read visually by single investigator. When the number of colonies exceeded 500 per plate, counting was stopped because of overgrowth of the microorganisms on the plate and difficulty in determining individual colonies.

While evaluating the results obtained in the study; SPSS version 24.0 statistical package programme was used for the statistical analyses. Kolmogorov-Smirnov test was used for whether the reproduction measurements were normally disturbed or not. Since most of the measurements were normally distributed, parametric methods were preferred. Anova test was used to compare the measurements between hours; and the bonferroni test was used to determine the group that caused the difference. Results were evaluated at $95 \%$ confidence interval and $p<0.05$ significance level.

\section{RESULTS}

The number of CFUs/ml of Staphylococus aureus, Pseudomonas aeruginosa, Acinetobacter baumanni and Candida albicans calculated from colonies counted on inoculated plates, in three different anesthetic drugs and saline with three different temperatures are listed in Table I and Figures 1-4.

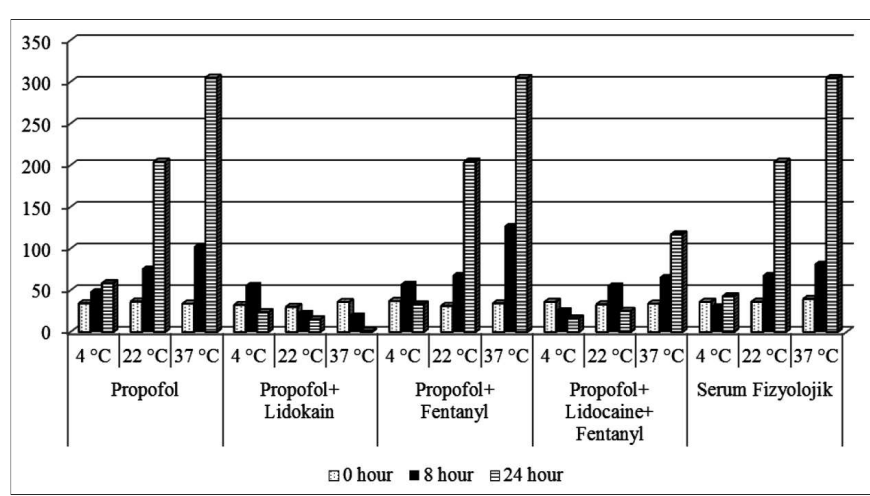

Figure 1: Growth of pseudomonas aeruginosa in five solutions in 0-8-24 hours at $40-22-37^{\circ} \mathrm{C}$.

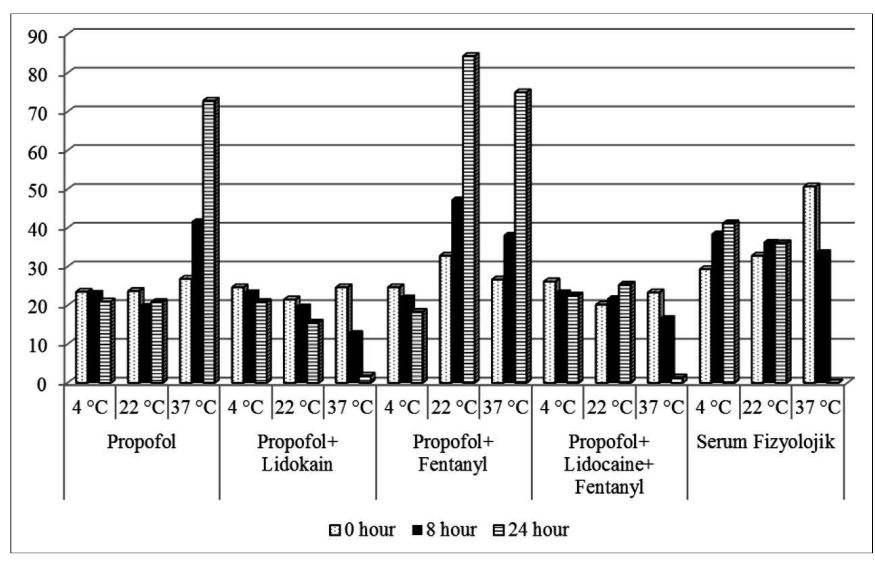

Figure 2: Growth of staphylococcus aureus in five solutions in 0-8-24 hours at $4-22-37^{\circ} \mathrm{C}$.

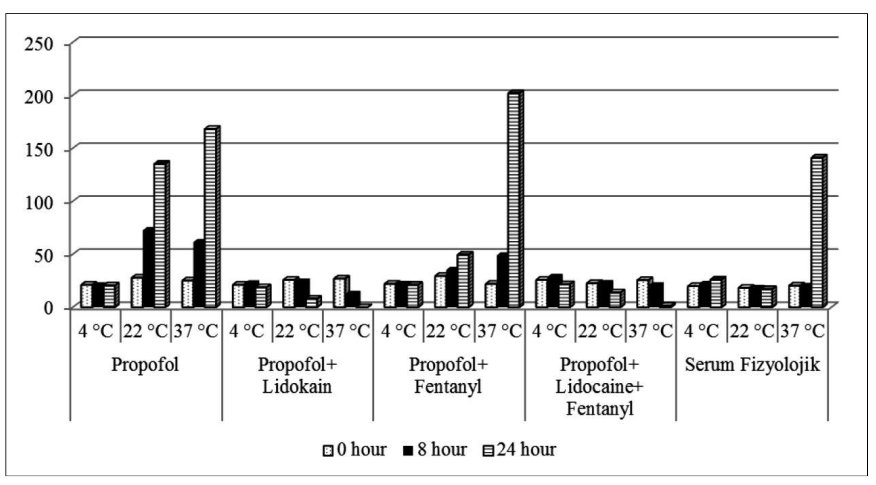

Figure 3: Growth of acinetobacter baumanni in five solutions in 0-8-24 hours at $4-22-37^{\circ} \mathrm{C}$

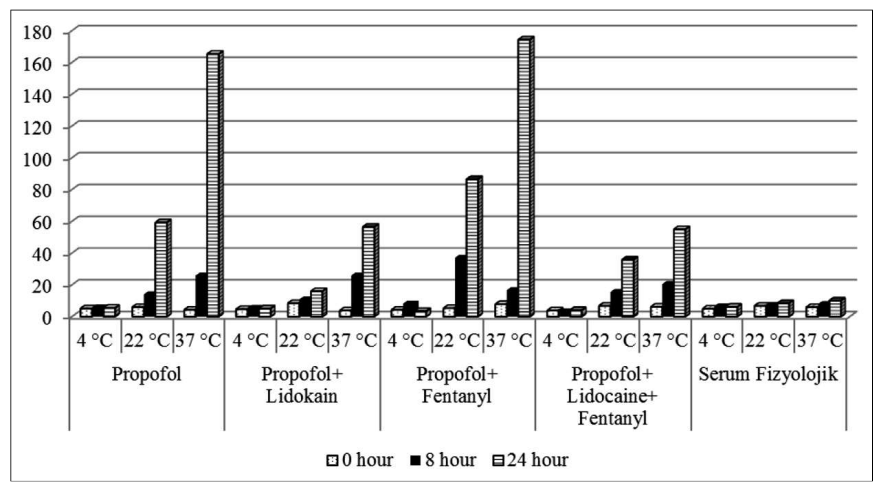

Figure 4: Growth of candida albicans in five solutions in 0-8-24 hours at $4-22-37^{\circ} \mathrm{C}$. 
Table I: Growth of the organisms in five solutions in $0-8-24$ hours at $4-22-37^{\circ} \mathrm{C}(\mathrm{CFU} / \mathrm{mL})$.

\begin{tabular}{|c|c|c|c|c|}
\hline & 0 hour (Mean \pm SD) & 8 hour (Mean \pm SD) & 24 hour (Mean \pm SD) & $\mathrm{p}$ \\
\hline $\begin{array}{l}\text { Pseudomonas aeruginosa } \\
4^{\circ} \mathrm{C} \\
\text { Propofol } \\
\text { Propofol+Lidocaine } \\
\text { Propofol+Fentanyl } \\
\text { Propofol+Lidocaine+Fentanyl } \\
\text { Physiological Saline } \\
22^{\circ} \mathrm{C} \\
\text { Propofol } \\
\text { Propofol+Lidocaine } \\
\text { Propofol+Fentanyl } \\
\text { Propofol+Lidocaine+Fentanyl } \\
\text { Physiological Saline } \\
37^{\circ} \mathrm{C} \\
\text { Propofol } \\
\text { Propofol+Lidocaine } \\
\text { Propofol+Fentanyl } \\
\text { Propofol+Lidocaine+Fentanyl } \\
\text { Physiological Saline }\end{array}$ & $\begin{array}{c}34.5 \pm 11.47 \\
32.5 \pm 4.55 \\
37.17 \pm 10.23 \\
36.17 \pm 8.35 \\
36.17 \pm 9.06 \\
\\
36.67 \pm 6.92 \\
30.17 \pm 6.911 \\
31.33 \pm 6.02 \\
33.17 \pm 8.52 \\
36.33 \pm 10.73 \\
\\
34 \pm 8.74 \\
36 \pm 9.3 \\
34.33 \pm 7.89 \\
34.0 \pm 4.6 \\
39.67 \pm 8.87\end{array}$ & $\begin{array}{c}48.67 \pm 15.5 \\
56 \pm 6.39 \\
57.5 \pm 8.62 \\
25.83 \pm 4.36 \\
30.67 \pm 14.22 \\
\\
76.17 \pm 8.52 \\
22.67 \pm 5.16 \\
68.17 \pm 16.44 \\
55.67 \pm 10.44 \\
68.17 \pm 24.79 \\
102.67 \pm 76.8 \\
19.67 \pm 7.2 \\
127.17 \pm 58.08 \\
65.67 \pm 10.56 \\
81.67 \pm 14.21\end{array}$ & $\begin{array}{c}58.5 \pm 15.07 \\
23.83 \pm 4.92 \\
33 \pm 10.75 \\
16.17 \pm 4.88 \\
42.83 \pm 10.5 \\
\\
204.17 \pm 2.64 \\
15.17 \pm 2.93 \\
204.33 \pm 2.58 \\
25.33 \pm 6.68 \\
204.17 \pm 2.32 \\
\\
305 \pm 3.22 \\
1.33 \pm 1.03 \\
304.83 \pm 2.79 \\
117.17 \pm 27.37 \\
304.67 \pm 2.8\end{array}$ & $\begin{array}{l}0.032 \\
0.000 \\
0.001 \\
0.000 \\
0.217 \\
\\
0.000 \\
0.001 \\
0.000 \\
0.000 \\
0.000\end{array}$ \\
\hline $\begin{array}{l}\text { Staphylococus aureus } \\
4^{\circ} \mathrm{C} \\
\text { Propofol } \\
\text { Propofol+Lidocaine } \\
\text { Propofol+Fentanyl } \\
\text { Propofol+Lidocaine+Fentanyl } \\
\text { Physiological Saline } \\
22^{\circ} \mathrm{C} \\
\text { Propofol } \\
\text { Propofol+Lidocaine } \\
\text { Propofol+Fentanyl } \\
\text { Propofol+Lidocaine+Fentanyl } \\
\text { Physiological Saline } \\
37^{\circ} \mathrm{C} \\
\text { Propofol } \\
\text { Propofol+Lidocain } \\
\text { Propofol+Fentanyl } \\
\text { Propofol+Lidocaine+Fentanyl } \\
\text { Physiological Saline }\end{array}$ & $\begin{array}{c}23.5 \pm 3.78 \\
24.67 \pm 9.33 \\
24.67 \pm 9.83 \\
26.17 \pm 5.64 \\
29.33 \pm 6.56 \\
\\
23.67 \pm 5.92 \\
21.5 \pm 9.16 \\
32.83 \pm 3.54 \\
20.17 \pm 3.82 \\
32.83 \pm 6.65 \\
\\
26.83 \pm 6.52 \\
24.67 \pm 4.46 \\
26.67 \pm 11.59 \\
23.33 \pm 9.91 \\
50.67 \pm 27.51\end{array}$ & $\begin{array}{c}23.17 \pm 6.27 \\
23.33 \pm 11.98 \\
22 \pm 12.18 \\
23.33 \pm 9.07 \\
38.5 \pm 5.68 \\
\\
19.83 \pm 7.36 \\
19.67 \pm 4.55 \\
47.33 \pm 4.76 \\
21.83 \pm 4.31 \\
36.33 \pm 11.55 \\
\\
41.67 \pm 13.85 \\
12.83 \pm 2.56 \\
38.17 \pm 22.23 \\
16.67 \pm 13.6 \\
33.67 \pm 25.63\end{array}$ & $\begin{array}{c}21 \pm 4.65 \\
20.83 \pm 8.5 \\
18.33 \pm 9.54 \\
22.5 \pm 11.26 \\
41.17 \pm 6.65 \\
\\
20.83 \pm 7.57 \\
15.5 \pm 6.95 \\
84.33 \pm 9.65 \\
25.33 \pm 6.19 \\
36 \pm 10.86 \\
\\
72.83 \pm 11.13 \\
1.83 \pm 1.6 \\
75 \pm 20.75 \\
1.33 \pm 1.51 \\
0 \pm 0\end{array}$ & $\begin{array}{l}0.652 \\
0.801 \\
0.593 \\
0.762 \\
0.014 \\
\\
0.625 \\
0.354 \\
0.000 \\
0.207 \\
0.799 \\
\\
0.000 \\
0.000 \\
0.001 \\
0.004 \\
0.003\end{array}$ \\
\hline $\begin{array}{l}\text { Acinetobacter baumanni } \\
4^{\circ} \mathrm{C} \\
\text { Propofol } \\
\text { Propofol+Lidokain } \\
\text { Propofol+Fentanyl } \\
\text { Propofol+Lidocaine+Fentanyl } \\
\text { Physiological Saline } \\
22^{\circ} \mathrm{C} \\
\text { Propofol } \\
\text { Propofol+Lidokain } \\
\text { Propofol+Fentanyl } \\
\text { Propofol+Lidocaine+Fentanyl } \\
\text { Physiological Saline } \\
37^{\circ} \mathrm{C} \\
\text { Propofol } \\
\text { Propofol+Lidocaine } \\
\text { Propofol+Fentanyl } \\
\text { Propofol+Lidocaine+Fentanyl } \\
\text { Physiological Saline }\end{array}$ & $\begin{array}{c}21.17 \pm 5.49 \\
21.17 \pm 6.52 \\
22 \pm 5.18 \\
25.83 \pm 5.12 \\
19.83 \pm 6.31 \\
\\
27.83 \pm 4.96 \\
25.83 \pm 4.17 \\
29.5 \pm 5.24 \\
22.67 \pm 2.16 \\
18.33 \pm 5.16 \\
\\
25.17 \pm 4.12 \\
27 \pm 6.07 \\
22 \pm 6.48 \\
25.5 \pm 5.68 \\
20.33 \pm 3.01\end{array}$ & $\begin{array}{c}20.67 \pm 5.92 \\
22.5 \pm 4.76 \\
22.17 \pm 3.25 \\
28.67 \pm 6.56 \\
22.17 \pm 6.55 \\
\\
72.67 \pm 9.11 \\
24.17 \pm 7.57 \\
35.33 \pm 21.74 \\
22.83 \pm 9.99 \\
18.17 \pm 4.17 \\
\\
61.5 \pm 16.36 \\
12.5 \pm 6.44 \\
49 \pm 8.29 \\
20.67 \pm 2.58 \\
20 \pm 4.24\end{array}$ & $\begin{array}{c}20.5 \pm 6.19 \\
18.83 \pm 5.78 \\
21.17 \pm 3.76 \\
21.67 \pm 6.95 \\
26 \pm 6.84 \\
\\
135.17 \pm 26.09 \\
8 \pm 4.24 \\
49.5 \pm 52.89 \\
13.83 \pm 1.33 \\
17 \pm 2.61 \\
168.17 \pm 51.64 \\
0 \pm 0 \\
201.83 \pm 0.75 \\
1.5 \pm 1.38 \\
141.17 \pm 20.72\end{array}$ & $\begin{array}{l}0.979 \\
0.547 \\
0.905 \\
0.184 \\
0.290 \\
\\
0.000 \\
0.000 \\
0.573 \\
0.030 \\
0.831 \\
\\
0.000 \\
0.000 \\
0.000 \\
0.000 \\
0.000\end{array}$ \\
\hline $\begin{array}{l}\text { Candida albicans } \\
4^{\circ} \mathrm{C} \\
\text { Propofol } \\
\text { Propofol+Lidocaine } \\
\text { Propofol+Fentanyl } \\
\text { Propofol+Lidocaine+Fentanyl } \\
\text { Physiological Saline } \\
22^{\circ} \mathrm{C} \\
\text { Propofol } \\
\text { Propofol+Lidocaine } \\
\text { Propofol+Fentanyl } \\
\text { Propofol+Lidocaine+Fentanyl } \\
\text { Physiological Saline } \\
37^{\circ} \mathrm{C} \\
\text { Propofol } \\
\text { Propofol+Lidocaine } \\
\text { Propofol+Fentanyl } \\
\text { Propofol+Lidocaine+Fentanyl } \\
\text { Physiological Saline }\end{array}$ & $\begin{array}{c}5.17 \pm 2.14 \\
4.67 \pm 2.8 \\
4.33 \pm 2.34 \\
3.83 \pm 2.64 \\
5 \pm 2.83 \\
\\
6.00 \pm 3.69 \\
8.5 \pm 5.61 \\
5.33 \pm 2.16 \\
6.83 \pm 5.19 \\
6.83 \pm 3.87 \\
\\
4.33 \pm 3.44 \\
3.83 \pm 2.14 \\
7.83 \pm 5.67 \\
6.17 \pm 6.55 \\
6 \pm 3.52\end{array}$ & $\begin{array}{c}5.83 \pm 6.08 \\
5.5 \pm 5.24 \\
8.17 \pm 10.59 \\
3.33 \pm 2.66 \\
6.5 \pm 4.14 \\
\\
14.00 \pm 14.71 \\
10.83 \pm 12.21 \\
37 \pm 37.35 \\
15.5 \pm 13.95 \\
7.33 \pm 8.19 \\
\\
25.83 \pm 24.4 \\
25.83 \pm 19.5 \\
16.67 \pm 15.02 \\
20.5 \pm 26.24 \\
7.83 \pm 8.28\end{array}$ & $\begin{array}{c}5.5 \pm 4.14 \\
5.17 \pm 3.87 \\
3.5 \pm 2.17 \\
4.17 \pm 3.54 \\
6.17 \pm 5.12 \\
\\
59.33 \pm 33.74 \\
16 \pm 21.79 \\
86.5 \pm 43.91 \\
35.83 \pm 20.82 \\
8.5 \pm 10.29 \\
\\
165.33 \pm 26.23 \\
56.5 \pm 47.35 \\
174.33 \pm 24.91 \\
55 \pm 61.79 \\
10.17 \pm 8.08\end{array}$ & $\begin{array}{l}0.967 \\
0.939 \\
0.423 \\
0.889 \\
0.807 \\
\\
0.001 \\
0.674 \\
0.003 \\
0.012 \\
0.933\end{array}$ \\
\hline
\end{tabular}


The results of microbial growth were not the same in all preparations due to different levels of resistance or behavior of microorganisms.

Saline $0.9 \%$ solution allowed bacterial counts to be sustained at a static level for up to 24 hours except for peudomonas and acinetobacter baumanni which increased significantly at 24 hours at $37^{\circ} \mathrm{C}$ and for staphylococcus aureus which decreased significantly at $37^{\circ} \mathrm{C}$. No significant growth of candida albicans occurred in saline.

In general propofol supported the growth of microorganisms. Fentanyl with propofol also promoted the growth, especially at $8^{\text {th }}$ and $24^{\text {th }}$ hours; but when combined with lidocaine, the number of CFUs was reduced significantly compared with propofol +fentanyl group. Lidocaine inhibited the growth of microorganisms in all the solutions except for candida albicans.

\section{DISCUSSION}

Postoperative nosocomial infections are known to increase patient morbidity and mortality, increasing healthcare costs and reducing hospital management efficiency. ${ }^{14}$ It is known that propofol emulsion is an excellent vehicle for supporting the growth of several microorganisms. The correct handling of propofol ampules with steril tecnique by anesthesiologists is highly recommended. Some investigations showed that when propofol ampule is opened, nonsteril glass fragments from the exterior of the ampule often fall into the emülsion and cause its contamination. 11 When the propofol is drawn up, it should not be stored after opening the ampule and should be used within 6 hours. Recommendations of use without delay is often difficult because small quantity of the drug during general anesthesia such as to increase the depth of anesthesia, reduce the intubation response and laringospasm.6,15

However, infusions of propofol may last for several hours either in the operating room or ICU. The risk of colonisation might be minimised, if propofol could be used when mixed with a compatibl drug. Therefore, antimicrobial effect of some drugs such as thiopental, methohexital, etomidate, ketamine and local anestetics are investigated. 8

In common use, propofol, lidocaine and fentanyl are applied during induction. Intravenous injection of propofol causes pain which is mostly minimised with lidocaine. Fentanyl is applied for analgesia and for preventing hemodynamic changes due to stress response.

There are few studies about the inpact of fentanyl on bacterial growth. In a study done by Isert, 13 it was reported that fentanyl is compatible with propofol. Graystone et al. examined intensive care drug infusions which included fentanyl citrate and reported that it was bactericidal. 10 Remifentanil, which is an analog of fentanyl, was also stated to decrease bacterial growth. 16,17

Tamai-Shacooriz et al. in their investigation, reported that sufentanil increased the antibacterial activity of bupivacaine but not ropivacaine. ${ }^{9}$

Antibacterial effect of lidocaine was shown in several investigations. 4,12,18 Several authors have investigated whether the addition of local anesthetics confers microbial growth inhibition.18-20 Sakuragi et al. found colony counts of $E$. Coli to be significantly lower after exposure to either lidocaine $(1 \%, 2 \%$ or $4 \%)$ or lidocaine $(0.25 \%-4 \%)$ - propofol mixtures, leading to the conclusion that lidocaine even confers bacteriostatic activity when added to extrinsically contaminated solutions of propofol. 21

In this study, it was also investigated whether combination of lidocaine and fentanyl with propofol produce an added effect to reduce the infectious complications due to accidentally contaminated propofol. Lidocaine inhibited bacterial growth of pseudomonas aeruginosa, acinetobacter baumanni and staphylococus aureus with increasing effect towards 24 hours at $37^{\circ} \mathrm{C}$. Lidocaine also controlled the microbial growth when mixed with fentanyl. Contrary to the previous research, in this study, fentanyl significantly supported microbial growth of all the organisms at 8 and 24 hours. Pseudomonas aeruginosa, acinetobacter baumanni and staphylococus aureus increased significantly in saline which was fungicidal on candida albicans.

Temperature has impact on bacterial growth. ${ }^{22}$ Crowter et al. reported that the lower temperature may reduce the growth of staphylococus aureus. ${ }^{23}$ Similarly, in this study, there were increased growth of staphylococus aureus, pseudomonas aeruginosa, acinetobacter baumanni and candida albicans at $37^{\circ} \mathrm{C}$ in solutions except for the one containing lidocaine.

In postoperative surgical site infections traced to the use of propofol, staphylococcus aureus was the the most identified etiologic agent so many investigations about propofol linked infections were carried out.7,11

In combinations of propofol, propofol+fentanyl and saline, CFUs were observed at $4^{\circ} \mathrm{C}$ and $22^{\circ} \mathrm{C}$, at 8 and 24 hours after inoculation except for staphylococcus aureus. It grew at $37^{\circ} \mathrm{C}$, after 24 hours. Late proliferation of staphycoccus was seen in some other studies.2,5

Investigations about acinetobacter baumanni is few as it more often seen in ICU. Multi resistant clinical isolate of acinetobacter baumanni is included in this study. Lidocaine also inhibited its growth with decreasing effect towards 24 hours at $37^{\circ} \mathrm{C}$.

\section{CONCLUSION}

Lidocaine was shown to have antibacterial effect, which carries advantage for inhibiting infections due to propofol; but aseptic technique is essential during preparation of 
propofol infusions. Fentanyl like propofol also promoted the growth, especially at room and body temperatures.

\section{CONFLICT OF INTEREST:}

Authors declared no conflict of interest.

\section{AUTHORS' CONTRIBUTION:}

HAA: Project design, literatüre review, article writing. EB: All microbiological examinations, literatüre review. SK: Literature review, manuscript checking for publishing. HS: All statistical examinations, literatüre review.

VBU: Literatüre review, helping microbiological examination.

\section{REFERENCES}

1. Topal A, Bilgin H, Ozakin C, Gedikoglu S, Gul NY. Growth of staphylococcus aureus, candida albicans, escherichia coli and pseudomonas aeruginosa in propofol, thiopental and a 1:1 propofol-thiopental mixture. J Anim Vet Adv 2010; 9:1432-5.

2. Güzelant A, Apiliogullari S, Kara I, Turhan V, Apiliogullari B, Yilmaz $\mathrm{H}$, et al. The preventive effect of diphenhydramine on bacterial growth in propofol: A laboratory study. Eur $J$ Anaesthesiol 2008; 25:737-40.

3. Baker MT, Naguib M. Propofol: The challenges of formulation. Anesthesiology 2005; 103:860-76.

4. Ozer Z, Ozturk C, Altunkan AA, Cinel I, Oral U. Inhibition of bacterial growth by lignocaine in propofol emulsion. Anaesth Intensive Care 2002; 30:179-82.

5. Strachan FA, Mansel JC, Clutton RE. A comparison of microbial growth in alfaxalone, propofol and thiopental. J Small Anim Pract 2008; 49:186-90.

6. King CA, Ogg M. Safe injection practices for administration of propofol. AORN J 2012; 95:365-72.

7. Langevin PB, Gravenstein N, Doyle TJ, Roberts SA, Skinner S, Langevin SO, et al. Growth of Staphylococcus aureus in Diprivan and Intralipid: implications on the pathogenesis of infections. Anesthesiology 1999; 91:1394-400.

8. Keles GT, Kurutepe S, Tok D, Gazi H, Dinç G. Comparison of antimicrobial effects of dexmedetomidine and etomidate-lipuro with those of propofol and midazolam. Eur $J$ Anaesthesiol 2006; 23:1037-40.

9. Tamanai-Shacoori Z, Shacoori V, Vo Van JM, Robert JC, Bonnaure-Mallet $M$. Sufentanil modifies the antibacterial activity of bupivacaine and ropivacaine. Can J Anaesth 2004; 51:911-4.
10. Graystone S, Wells MF, Farrell DJ. Do intensive care drug infusions support microbial growth? Anaesth Intensive Care 1997; 25:640-2.

11. Sosis MB, Braverman B. Growth of staphylococcus aureus in four intravenous anesthetics. Anesth Analg 1993; 77:766-8.

12. Vidovich MI, Peterson LR, Wong HY. The effect of lidocaine on bacterial growth in propofol. Anesth Analg 1999; 88:936-8.

13. Isert PR, Lee D, Naidoo D, Carasso ML, Kennedy RA. Compatibility of propofol, fentanyl, and vecuronium mixtures designed for potential use in anesthesia and patient transport. J Clin Anesth 1996; 8:329-36.

14. Schaberg DR, Haley RW, Highsmith AK, Anderson RL, McGowan JE Jr. Nosocomial bacteriuria: A prospective study of case clustering and antimicrobial resistance. Ann Intern Med 1980; 93:420-4.

15. Raveendra US, Soori R, Karnekar VK, Nayak SV and Bangera A. Incidence and pattern of bacterial growth in propofol vial - an invitro study. NUJHS 2016; 6:51-6.

16. Erden IA, Gülmez D, Pamuk AG, Akincia SB, Hasçelik G, Aypar U. The growth of bacteria in infusion drugs: Propofol $2 \%$ supports growth when remifentanil and pantoprazole do not. Braz $J$ Anesthesiol 2013; 63:466-72.

17. Apan TZ, Apan A, Sahin S, Cakirca M. Antibacterial activity of remifentanil and mixtures of remifentanil and propofol. $J$ Clin Anesth 2007; 19:346-50.

18. Johnson SM, Saint John BE, Dine AP. Local anesthetics as antimicrobial agents: A review. Surg Infect (Larchmt) 2008; 9:205-13.

19. Gajraj RJ, Hodson MJ, Gillespie JA, Kenny GN, Scott NB. Antibacterial activity of lidocaine in mixtures with Diprivan. $\mathrm{Br} J$ Anaesth 1998; 81:444-8.

20. Rosenberg PH, Renkonen OV. Antimicrobial activity of bupivacaine and morphine. Anesthesiology 1985; 62:178-9.

21. Sakuragi T, Yanagisawa K, Shirai Y, Dan K. Growth of escherichia coli in propofol, lidocaine, and mixtures of propofol and lidocaine. Acta Anaesthesiol Scand 1999; 43:476-9.

22. Aydin N, Aydin N, Gultekin B, Ozgun S, Gurel A. Bacterial contamination of propofol: The effects of temperature and lidocaine. Eur J Anaesthesiol 2002; 19:455-8.

23. Crowther J, Hrazdil J, Jolly DT, Galbraith JC, Greacen M, Grace M. Growth of micro-organisms in propofol, thiopental, and a 1:1 mixture of propofol and thiopental. Anesth Analg 1996; 82:475-8. 